\title{
Calcification rates of the massive coral Siderastrea siderea and crustose coralline algae along the Florida Keys (USA) outer-reef tract
}

\author{
I. B. Kuffner $\cdot$ T. D. Hickey $\cdot$ J. M. Morrison
}

Received: 30 January 2013/ Accepted: 24 May 2013/Published online: 8 June 2013

(c) The Author(s) 2013. This article is published with open access at Springerlink.com

\begin{abstract}
Coral reefs are degrading on a global scale, and rates of reef-organism calcification are predicted to decline due to ocean warming and acidification. Systematic measurements of calcification over space and time are necessary to detect change resulting from environmental stressors. We established a network of calcification monitoring stations at four managed reefs along the outer Florida Keys Reef Tract (FKRT) from Miami to the Dry Tortugas. Eighty colonies (in two sequential sets of 40) of the reef-building coral, Siderastrea siderea, were transplanted to fixed apparatus that allowed repetitive detachment for buoyant weighing every 6 months. Algalrecruitment tiles were also deployed during each weighing interval to measure net calcification of the crustose coralline algal (CCA) community. Coral-calcification rates were an order of magnitude greater than those of CCA. Rates of coral calcification were seasonal (summer calcification was $53 \%$ greater than winter), and corals in the Dry Tortugas calcified $48 \%$ faster than those at the other three sites. Linear extension rates were also highest in the Dry Tortugas, whereas percent area of the coral skeletons excavated by bioeroding fauna was lowest. The spatial patterns in net coral calcification revealed here correlate well with Holocene reef thickness along the FKRT and, in part,
\end{abstract}

Communicated by Geology Editor Prof. Bernhard Riegl

Electronic supplementary material The online version of this article (doi:10.1007/s00338-013-1047-8) contains supplementary material, which is available to authorized users.

I. B. Kuffner $(\bowtie) \cdot$ T. D. Hickey · J. M. Morrison

St. Petersburg Coastal and Marine Science Center,

U.S. Geological Survey, 600 4th Street South,

St. Petersburg, FL 33701, USA

e-mail: ikuffner@usgs.gov support the "inimical waters hypothesis" proposed by Ginsburg, Hudson, and Shinn almost 50 yrs ago to explain reef development in this region. Due to the homogeneity in coral-calcification rates among the three main Keys sites, we recommend refinement of this hypothesis and suggest that water-quality variables (e.g., carbonate mineral saturation state, dissolved and particulate organic matter, light attenuation) be monitored alongside calcification in future studies. Our results demonstrate that our calcification monitoring network presents a feasible and worthwhile approach to quantifying potential impacts of ocean acidification, warming, and/or deteriorating water quality on the process of calcification.

Keywords Coral growth - CCA - Buoyant weight . Bioerosion - Ocean acidification · Climate change

\section{Introduction}

Coral reefs are the largest biomineralized structures on the planet. They function as barriers to coastal hazards by protecting land from hurricanes and tsunamis, provide essential habitat for fisheries, support tourism and recreational industries, and provide sand for beaches through the natural process of erosion; however, coral reef ecosystems are becoming degraded on a global scale (Pandolfi et al. 2003). Declines in coral populations are largely a result of ocean warming via coral bleaching and disease mortality (Aronson et al. 2003; Veron et al. 2009). With respect to trophic functioning and the ecosystem as a whole, overfishing (Jackson et al. 2001) and anthropogenic impact on water quality caused by land-use change (Fabricius 2005) are both significant stressors. While debate continues as to how scientists can best inform decision makers via 
research and monitoring in hopes of at least slowing the loss of coral reefs (Risk 1999; Hughes et al. 2010), understanding calcification, the constructive process responsible for the creation of reefs, is of utmost importance. Predicting future impacts of ocean warming and acidification on coral reefs will require more in situ studies (Frieler et al. 2013), including those that address the variables controlling calcification and reef accumulation over space and time.

The rate at which corals calcify can be influenced by multiple environmental variables including temperature (Shinn 1966; Jokiel and Coles 1977, 1990), water motion (Jokiel 1978; Dennison and Barnes 1988), solar irradiance (Falkowski et al. 1990), aragonite saturation state (Gattuso et al. 1998; Marubini et al. 2003), and inorganic nutrient levels (Marubini and Davies 1996). On shallow-water reefs, many of these environmental variables are dynamic on diurnal (Ohde and Van Woesik 1999) and seasonal (Gledhill et al. 2008) time scales. Super-annual trends in ocean warming (Winter et al. 1998; Chollett et al. 2012) and declining $\mathrm{pH}$ (ocean acidification, Bates 2007) over the past several decades have been confirmed by observational records around the globe. The majority of studies evaluating controls on coral calcification have been aquarium or sea-table experiments, and there are few supporting data from the field. Calcification of corals in captivity inversely correlates with $\left[\mathrm{H}^{+}\right]$and $p \mathrm{CO}_{2}$, and positively correlates with aragonite saturation state, carbonate ion concentration, dissolved inorganic carbon (DIC), and $\mathrm{pH}$ (Marubini and Atkinson 1999; Marubini et al. 2003; Reynaud et al. 2003; Anthony et al. 2008; Jokiel et al. 2008). Calcification response to temperature manipulations is curvilinear, increasing linearly until a regionally defined optimum, and then declining even before bleaching and mortality ensue (Coles and Jokiel 1978; Jokiel and Coles 1990).

Most field research on coral growth has involved measuring linear extension rates, visualized by slicing and
X-raying cores taken from living coral colonies and then measuring the width of density growth-band couplets, which are assumed to reflect annual growth (Knutson et al. 1972). Calcification rate is then routinely calculated by multiplying linear extension rate by the average bulk skeletal density (measured by various techniques) of each growth-band couplet. However, previous well-replicated studies have demonstrated high unexplained variance in linear extension within and among colonies living on the same area of reef (Hudson 1981a; Dodge and Brass 1984; Harriott 1999), and large assumptions are made regarding the time domain (see Discussion in Carricart-Ganivet 2011). Using this approach of retrospectively calculating calcification rate, the evidence connecting in situ coral growth to environmental trends is equivocal. Correlation has been demonstrated in some cases, showing declines in coral calcification as the oceans have warmed and acidified (Cooper et al. 2008; De'ath et al. 2009; Tanzil et al. 2009), but in some studies trends were not observed (Helmle et al. 2011; Vasquez-Bedoya et al. 2012) or observed only on certain reef types (Castillo et al. 2011) or regions, with high-latitude reefs even showing increases in calcification with time (Cooper et al. 2012).

The purpose of our study was to examine and quantify spatial and temporal (seasonal) variability in calcification rates by a reef-building coral, Siderastrea siderea, and by crustose coralline algal (CCA) communities on the Florida Keys Reef Tract (FKRT; Fig. 1). Like many reefs around the world, the reefs of the Florida Keys have undergone major degradation since the 1960s (Lidz et al. 2006; Palandro et al. 2008), but debate continues with regards to why (Voss 1973; Pandolfi et al. 2005) and what conservation management strategies to employ (Keller and Causey 2005). Detecting change in calcification rates and ascribing that change to ocean warming, ocean acidification, poor water quality, or any other variable will require a solid
Fig. 1 Map of the Florida Keys, USA, showing the locations of four calcification monitoring sites (arrows). Site names used are those of the adjacent National Data Buoy Center stations: Pulaski Shoal (PLS), Sombrero Key (SMK), Molasses Reef (MLR), and Fowey Rocks (FWY)

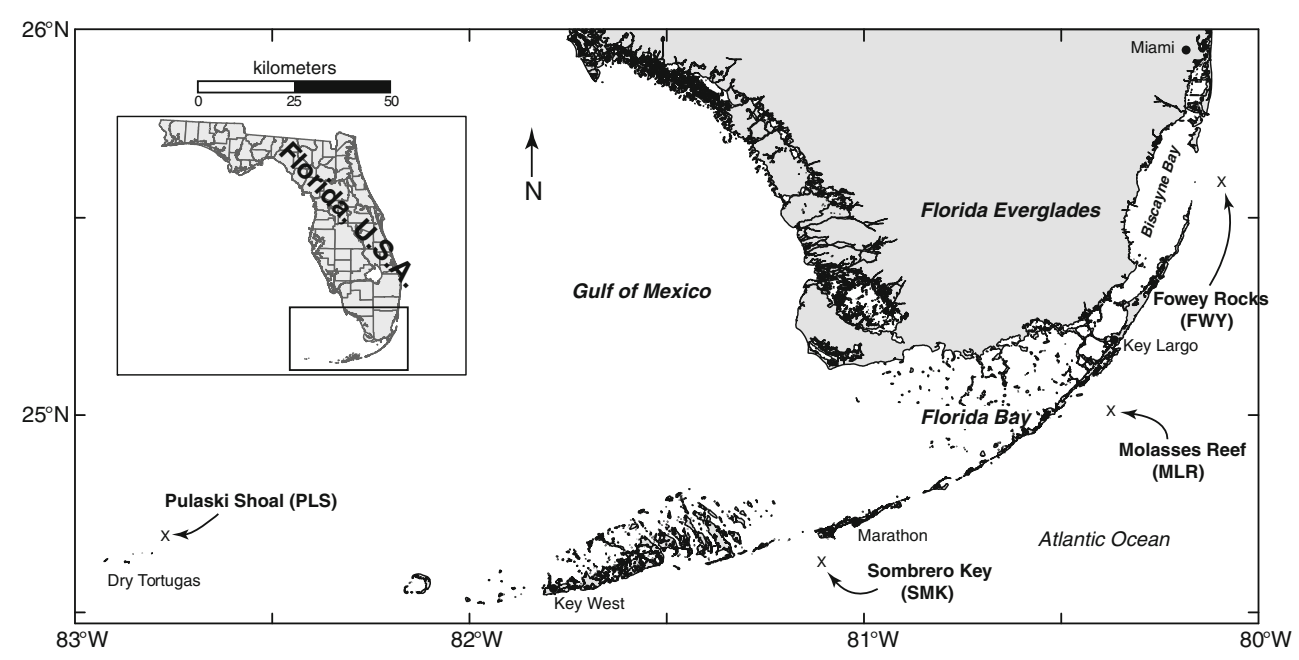


understanding of the natural range and variability in calcification rates that are apparent today. In order to address this, we transplanted 80 whole colonies of $S$. siderea to four outer-reef sites on the FKRT (Fig. 1) and measured coralcalcification rates directly via the buoyant weight method (Jokiel et al. 1978) over a 2-yr period. We simultaneously deployed algal-recruitment tiles to measure net calcification by the CCA community.

\section{Materials and methods}

The FKRT is a bank-reef system that runs semi-continuously along the length of the Florida Keys at $24.5-25.5^{\circ} \mathrm{N}$ latitude (Fig. 1). Four sites spanning $340 \mathrm{~km}$ of the reef tract were selected in shallow spur-and-groove or lowrelief hard-bottom habitat at a water depth of 4 to $6 \mathrm{~m}$. In addition to habitat, site selection was based upon the availability of meteorological data gathered by National Data Buoy Center (NDBC) stations (http://www.ndbc. noaa.gov/) and underwater oceanographic data gathered by the Sustained Ecological Research Related to Management of the Florida Keys Seascape (SEAKEYS) program. We established our sites on the reef within $225 \mathrm{~m}$ of the NDBC/SEAKEYS stations at Pulaski Shoal (PLS), Sombrero Key (SMK), Molasses Reef (MLR), and Fowey Rocks (FWY). The PLS site is within the boundaries of Dry Tortugas National Park, SMK and MLR are within Sanctuary Preservation Areas of the Florida Keys National Marine Sanctuary (FKNMS), and FWY is within Biscayne National Park. Global positioning system coordinates of the sites are included in Electronic Supplementary Material (ESM) Table S1.

We chose $S$. siderea because it is presently the most abundant massive species of reef-building coral on the FKRT (Lirman and Fong 2007), it is resistant to cold- and warm-water stress events (Colella et al. 2012), it is comparatively successful at sexual reproduction as opposed to the other FKRT reef builders (Lirman and Fong 2007), and it is proving to be a choice species for paleoclimate reconstruction in the Atlantic ocean (DeLong et al. 2011). Two batches of 40 corals were collected in two consecutive runs of the experiment, the first in spring/summer 2009 and the second in spring 2011. Corals were collected in 3-6 m water depth and from within $7 \mathrm{~km}$ of the monitoring sites except for FWY in 2009 ( $24 \mathrm{~km})$.

Each site was composed of ten stations (concrete blocks measuring $19 \times 19 \times 19 \mathrm{~cm}$; Fig. 2.) spaced $\sim 2-4 \mathrm{~m}$ from one another. Concrete blocks were securely fastened to the seafloor with two $15-\mathrm{cm}$ stainless-steel threaded rods embedded and epoxied into the substratum. We drilled a hole in center of the block's top surface so that a coral colony could be attached. Each coral was epoxied to a

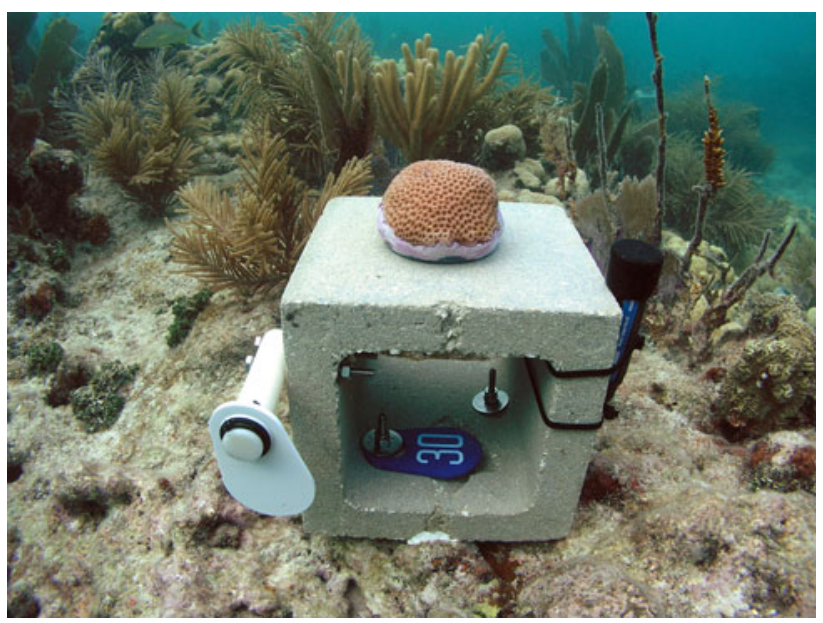

Fig. 2 Underwater photograph of a calcification station (1 of 40). Attached are a colony of $S$. siderea (top), a crustose coralline algae (CCA) accretion tile (white, on left), and a temperature logger (black, on right)

polyvinyl chloride disc cut from 9-mm thick sheeting and fitted with a $10-\mathrm{cm}$ long stainless-steel threaded bolt. The coral was then attached to the concrete block by sliding the bolt through the hole and fastening it with a wing nut.

Every 6 months, the corals were detached from the blocks, transported by boat (while submerged in seawater), buoyantly weighed on land (Jokiel et al. 1978), and returned to their blocks later that day. Change in buoyant mass was converted to dry mass using the equations in Jokiel et al. (1978) with a seawater density of $1.02 \mathrm{~g} \mathrm{~cm}^{-3}$ and an aragonite density of $2.93 \mathrm{~g} \mathrm{~cm}^{-3}$. Coral-calcification rate was calculated per day and normalized to $2 \mathrm{D}$ coral surface area, which was determined by measuring the "bird's eye" dimensions of length and width with calipers and calculating the area of an ellipse. At the start of the experiment and during springtime site visits, corals were vitally stained with alizarin red $\mathrm{S}$ to allow measurements of linear extension. The stain was added to the seawater $\left(15 \mathrm{mg} \mathrm{L}^{-1}\right)$ in the transport buckets, which were suspended by floating rings in the ocean in order to keep the corals at ambient seawater temperature during the 4-hour staining periods surrounding the solar zenith (roughly 11:00-15:00).

To measure calcification rates of the crustose coralline algal (CCA) community, we deployed plastic tiles ("pear" neck tags used in the livestock industry, National Band and Tag Co., Newport, KY, USA) at each visit to the stations and harvested the tiles deployed on the previous visit. We used pre-weighed, manufactured tiles so that samples did not have to be dissolved in order to measure CCA mass gained, allowing us to archive the samples. The tiles were oriented vertically to increase selectivity for the CCA community, leaving no "underside" to attract cryptic fauna 
(e.g., tunicates, bryozoans, and tube-forming worms). Harvested tiles were rinsed with tap water to remove loose sediments, photographed on each side, dried for $48 \mathrm{~h}$ at $60{ }^{\circ} \mathrm{C}$, and weighed to obtain the mass $\left(\mathrm{g} \mathrm{CaCO}_{3}\right)$ gained per day. Grazing intensity was estimated by counting the number of parrotfish-bite marks per tile.

Underwater temperature data were collected using HOBO $^{\circledR}$ Water Temp Pro v2 temperature loggers $\left(\right.$ Onset ${ }^{\circledR}$, Pocasset, MA, USA). Two loggers were deployed at each site attached to the side of the blocks (Fig. 2). The loggers collected temperature data every $15 \min (n=96$ per day).

Site visits were typically during November and May. Foul weather delayed Dry Tortugas visits on two occasions (PLS corals were instead weighed in July in 2010 and December in 2011). Data are reported here for four weighing intervals (Fig. 3); the first two are from the first batch of 40 corals and the second two from the second batch. The first batch of corals was sampled in May 2011 by taking two 4-mm-wide slices from each live coral using a modified tile saw. The remaining halves of the colonies were epoxied together and reattached to the seafloor (100\% of the colonies survived). The slabs were cleaned with a sonicator in distilled water, air dried, and photographed under a stereomicroscope to measure the distance from the alizarin red S stain line to the surface of the coral along the exothecal wall (six measurements per slab, two slabs per colony). The slabs were X-rayed to reveal the burrows and cavities made by bioeroding organisms. Linear extension $(\mathrm{mm})$ and the area of skeleton excavated $\left(\mathrm{mm}^{2}\right)$ were estimated using iSolution Capture $^{\circledR}$ version 3.1 image analysis software (IMT i-Solution Inc., Vancouver, BC, Canada). Coral density was calculated by dividing calcification rate by linear extension rate.

All statistical analyses were performed using the software package Statistix $@ 9$ (Analytical Software, Tallahassee, FL, USA). Dependent variables (coral and CCA calcification rates, CCA-tile grazing, temperature) were analyzed using two-way ANOVA with site, time interval, and the two-way interaction term in the model. Unless otherwise stated, the two-way interactions were not significant. For the variables measured on the coral slabs (first set of corals only), data were analyzed using one-way ANOVA by site. If the assumptions of ANOVA were not met (residuals not normally distributed, unequal variance among ANOVA cells), then the data were transformed as noted or a nonparametric Kruskal-Wallis $(\mathrm{K}-\mathrm{W})$ ANOVAlike test was used. Post hoc comparisons were made using Tukey's Honestly Significant Difference (HSD) or K-W all pairwise comparisons by site with alpha $=0.05$. To test for seasonal effects when appropriate (i.e., no two-way interaction), a linear contrast of winter versus summer time intervals was performed using a Student's $t$ test based upon the $a$ priori hypothesis that calcification would vary with season. Since there was no significant difference between the calcification rates of the two batches of corals at any of the sites (two-way ANOVA, site $\times$ batch $p=0.31$, batch $p=0.77)$, the data from the two batches of corals were pooled. Three of the 80 corals were removed from the dataset: two because they experienced extremely bad sponge infections wherein calcification was negative and one because it disappeared. Simple linear regression was used to examine the relationship between calcification rate and linear extension for the first batch of corals.
Fig. 3 Daily mean underwater temperature $\left({ }^{\circ} \mathrm{C}\right)$ at four Florida Keys outer-reef tract sites from April 2009 to May 2012. Dashed line at $30{ }^{\circ} \mathrm{C}$ marks a generalized bleaching threshold for most corals in the region. The vertical gray lines mark the four weighing intervals, the first two for the first 40 corals, and the second two for the second 40. Site abbreviations are Pulaski Shoal = PLS, Sombrero Key $=$ SMK, Molasses Reef $=$ MLR, and Fowey Rocks $=$ FWY

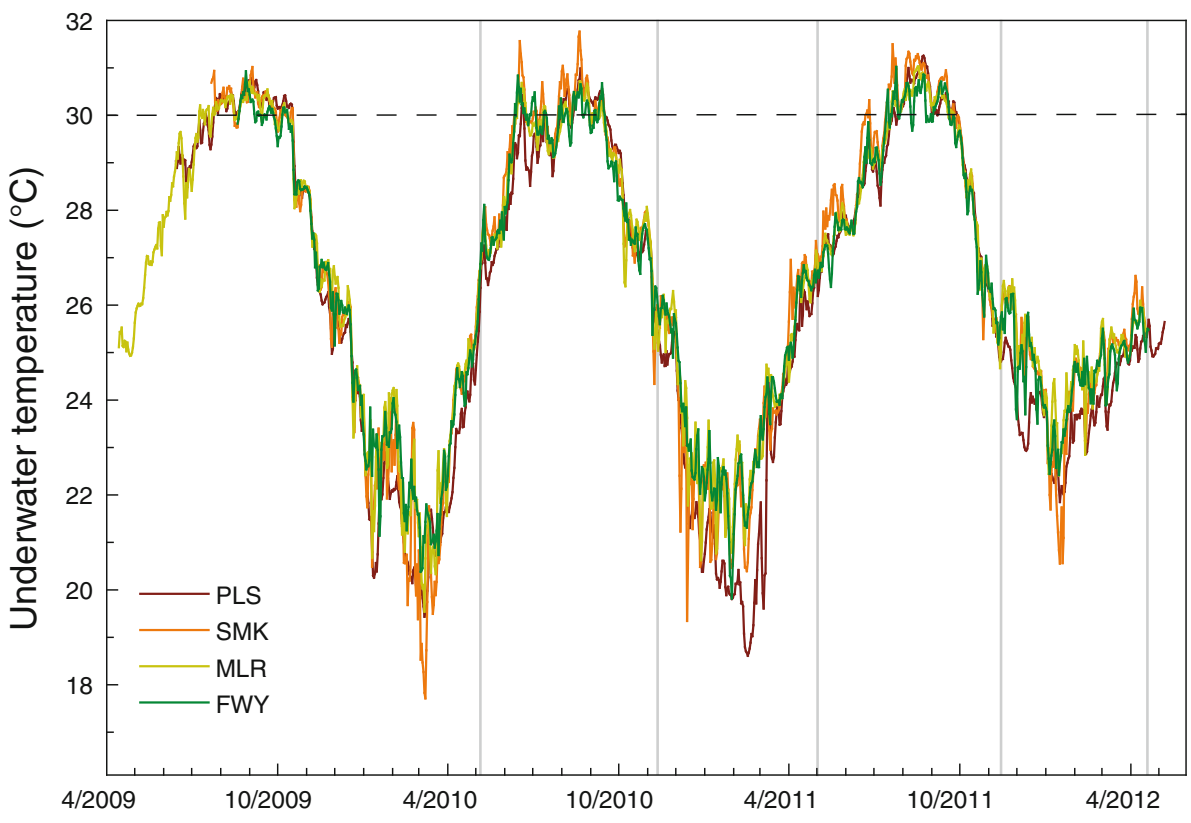




\section{Results}

The study-wide mean calcification rate of $S$. siderea from 2010 to 2012 was $2.7 \mathrm{mg} \mathrm{cm}^{-2} \mathrm{~d}^{-1}(n=77)$. Both time interval and site had significant effects on coral-calcification rates (two-way ANOVA, time $F=25.2, p<0.0001$, site $F=19.1, p<0.0001$ ) (Fig. 4a, ESM Table S1). Coral calcification was $53 \%$ faster during summer compared to winter (linear contrast, winter vs. summer $T=8.5$, $p<0.0001)$ and $48 \%$ faster in the Dry Tortugas compared to the three main Keys sites (Tukey's HSD by site, PLS $>$ MLR $=$ SMK $=$ FWY).

Mean annual linear extension was $2.6 \mathrm{~mm} \mathrm{yr}^{-1}(n=39)$ and significantly varied among the sites (Kruskal-Wallis [K-W] test, $H=16.4, p=0.001)$. Linear extension was greatest at PLS (mean $\pm \mathrm{SE}=3.1 \pm 0.1 \mathrm{~mm} \mathrm{yr}^{-1}$ ), but there was statistical overlap with FWY and SMK (K-W all pairwise comparisons by site, only PLS $>$ MLR). Linear extension and calcification rate had a significant positive relationship (least-squares linear regression, $R^{2}=0.50$,

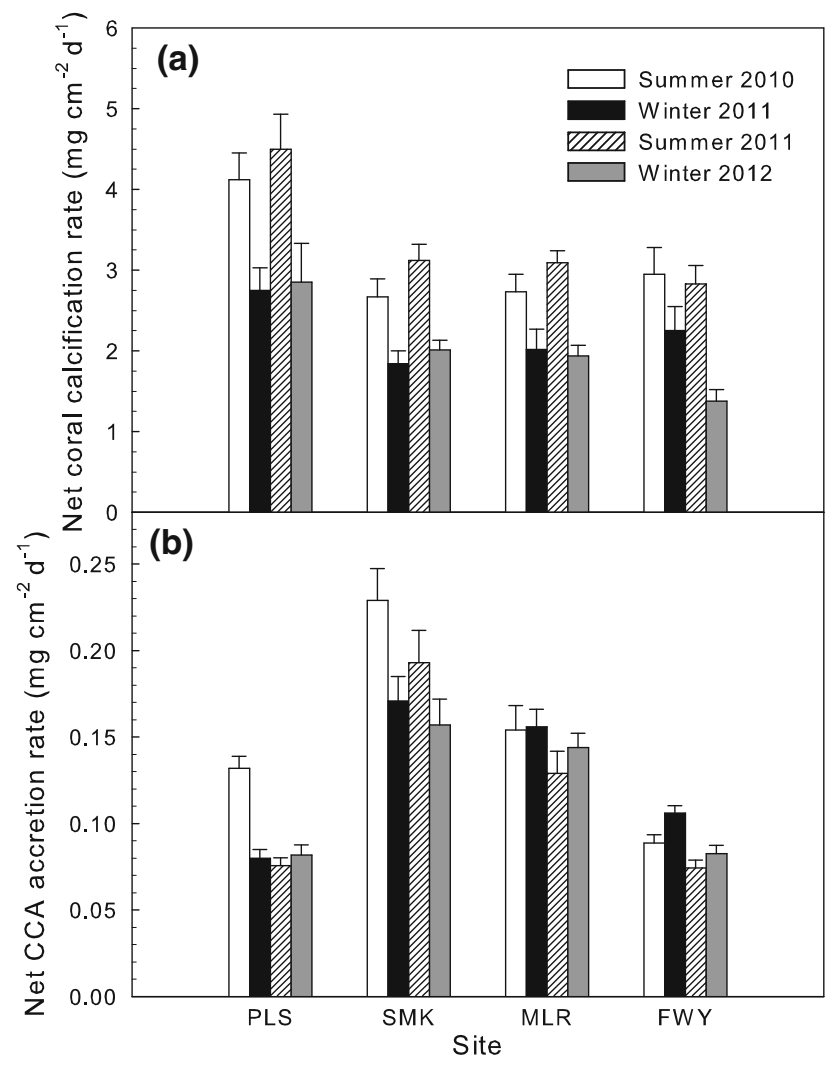

Fig. 4 Mean net coral-calcification rates $\left(\mathrm{mg} \mathrm{cm}^{-2} \mathrm{~d}^{-1}\right)$ of $S$. siderea colonies (a) and mean net accretion $\left(\mathrm{mg} \mathrm{cm}^{-2} \mathrm{~d}^{-1}\right)$ of crustose coralline algae (CCA) communities (b) at four sites in the Florida Keys. Error bars are \pm 1 SEM. Site abbreviations are Pulaski Shoal $=$ PLS, Sombrero Key $=$ SMK, Molasses Reef $=$ MLR, and Fowey Rocks $=$ FWY. The data in the figure and the GPS coordinates of the sites are presented in the electronic supplementary material, ESM Table S1 $p<0.0001)$. Density, calculated by dividing calcification rate by linear extension rate, was $3.7 \mathrm{~g} \mathrm{~cm}^{-3}$ overall, and did not statistically vary among sites $(\mathrm{K}-\mathrm{W}$ test, $H=4.6$, $p=0.20)$.

Percent of the skeleton excavated by macrobioeroders was statically different among sites $(\mathrm{K}-\mathrm{W}$ test, $H=12.9$, $p=0.005)$. Corals at PLS were the least excavated (mean $\pm \mathrm{SE}=3.7 \pm 1.0 \%$ ), statistically lower than MLR $(13.2 \pm 3.9 \%)$ and SMK $(11.3 \pm 1.7 \%)$, with FWY in between $(6.0 \pm 1.9 \%)$ and not statistically different from either group ( $\mathrm{K}-\mathrm{W}$ all pairwise comparisons by site).

Overall mean calcification of the CCA community was $0.13 \mathrm{mg} \mathrm{cm}^{-2} \mathrm{~d}^{-1}$, more than an order of magnitude less than the coral-calcification rate (Fig. 4b, ESM Table S1). Calcification by the CCA community did not show clear seasonal patterns (ANOVA two-way interaction (site $\times$ season) $F=6.31, p=0.0005)$. Although the significant two-way interaction makes it hard to draw conclusions about the main effects, the site effect was large (two-way ANOVA, site $F=69.2, p<0.0001$ ), with highest CCA calcification at SMK, followed by MLR, and the other two sites (Tukey's HSD by site, SMK $>$ MLR $>$ PLS $=$ FWY). It was evident from the many parrotfish feeding scars that grazing could have been an important factor in the experiment. Number of bite marks per tile varied among sites and was greatest at FWY (two-way ANOVA on squareroot transformed data, site $F=69.0, p<0.0001$, Tukey's HSD by site: FWY $>$ PLS $=$ MLR $=$ SMK).

Mean daily underwater temperature $\left({ }^{\circ} \mathrm{C}\right)$ averaged over the 2-yr period (Fig. 5a) was slightly cooler at PLS $(26.2 \pm 3.3 \mathrm{SD})$ and slightly warmer at SMK $(26.8 \pm 3.0$ $\mathrm{SD})$ compared to the other sites $(\mathrm{K}-\mathrm{W}$ test, $H=11.9$, $p=0.008, \mathrm{~K}-\mathrm{W}$ all pairwise comparisons, SMK $>$ PLS). Short-duration, site-specific temperature excursions were seen throughout the dataset (Fig. 3). Diurnal variability in temperature was strongly site specific (Fig. 5b; K-W test, $H=346, p<0.0001)$ and was clearly lowest at PLS, followed by MLR, and then the other two sites $(\mathrm{K}-\mathrm{W}$ all pairwise comparisons by site, $\mathrm{PLS}<\mathrm{MLR}<\mathrm{SMK}=$ FWY). Diurnal variability was greatest during winter months at the three main Keys sites, but PLS showed the greatest variability in summer (Fig. 5b).

\section{Discussion}

Our overall estimate of mean annual calcification for S. siderea was $0.99 \mathrm{~g} \mathrm{~cm}^{-2} \mathrm{yr}^{-1}$, which is within the range of values reported for in situ studies on other coral species using the buoyant weight technique as well as recent studies that calculated calcification rates using density and linear extension measurements of annual growth bands 


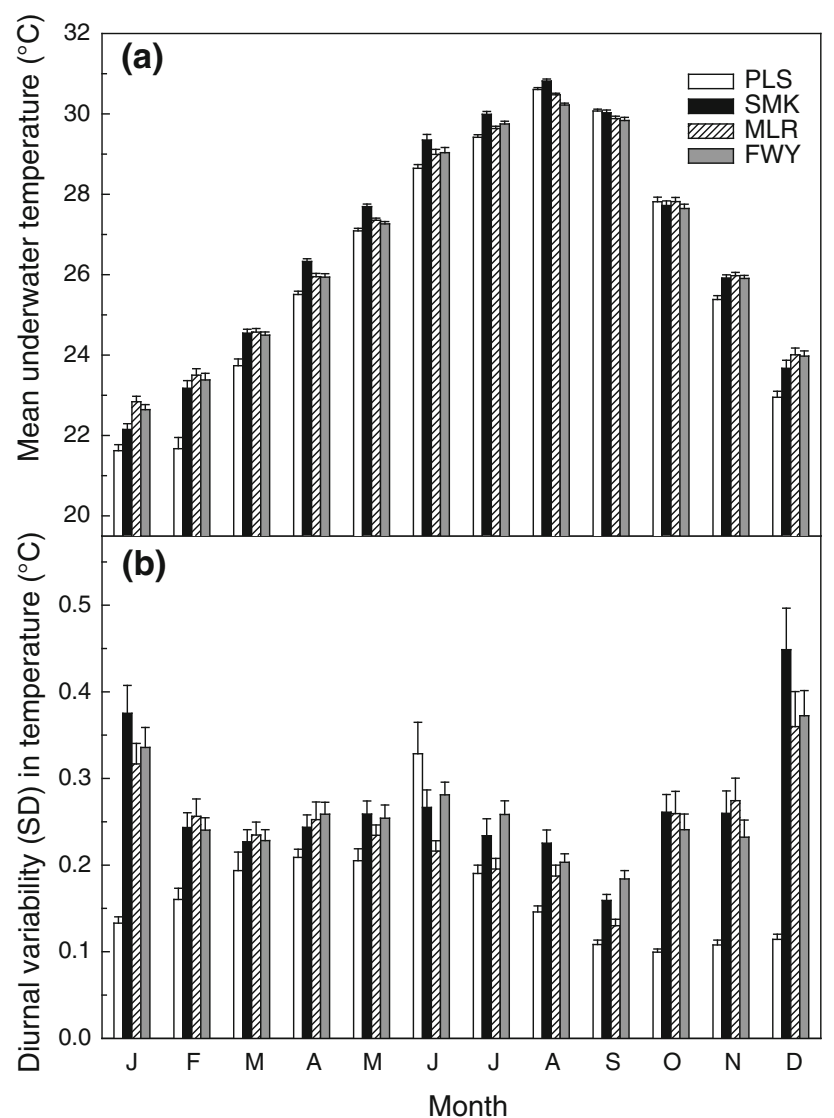

Fig. 5 Mean (a) and standard deviation (b) of mean $(n=96$ measurements per day) of daily underwater temperature $\left({ }^{\circ} \mathrm{C}\right)$ for each month over 2 yrs at four sites on the Florida Keys outer-reef tract. Error bars are \pm 1 SEM. Site abbreviations are Pulaski Shoal $=$ PLS, Sombrero Key $=$ SMK, Molasses Reef $=$ MLR, and Fowey Rocks $=$ FWY

(ESM Table S2). Surprisingly, the magnitude of the site effect (greatest calcification in the remote Dry Tortugas) was on par with the seasonal effect (greater calcification in summer); both were roughly $50 \%$. Mean temperature differences between sites cannot explain the spatial pattern because the four sites generally stayed within $1{ }^{\circ} \mathrm{C}$ of each other (Fig. 5a). However, there was a clear distinction among the sites with regards to the diurnal variability in temperature (Fig. 5b). While daily instability in temperature $<1{ }^{\circ} \mathrm{C}$ is unlikely to be a main driver in and of itself, it provides a "fingerprint" (most clearly seen in the winter months; Fig. 5b) indicating the tidally driven arrival of waters from more than one source. Movement of water through the Keys via tidal passes, into Hawk Channel (the shallow basin that runs parallel to and just seaward of the entire island chain), and out to the reef is clearly observed by satellite during cold fronts (Roberts et al. 1982). There is a net annual outflow of water through the tidal passes driven by higher sea level in Florida Bay relative to the Atlantic resulting from the complex interactions of tides, geomorphology, and prevailing winds (Lee and Smith 2002; Gibson et al. 2008).

The patterns in coral calcification we observed here are congruent with the Holocene geologic record of the FKRT. The accumulation of Holocene reef is $\sim 20 \mathrm{~m}$ thick in the Dry Tortugas, while the main Keys reefs have not appreciably accumulated more than a few vertical meters over the last 6,000 yrs (Shinn et al. 1977; Shinn 1980). Rising sea level started to flood the Florida peninsula around 6,000 yrs before present (BP), completely submerging the area that is now Florida Bay by 2000 BP (Lidz and Shinn 1991). Terrestrial influence of the Florida peninsula on water quality and basin-depth influence on annual temperature range of the waters delivered from the West Florida Shelf and Florida Bay through the Florida Keys tidal passes constitute the most parsimonious explanation for the pattern in reef accretion in the late Holocene; this is known as the "inimical waters" hypothesis (Hudson 1983; Lidz and Shinn 1991; Ginsburg and Shinn 1994). This hypothesis, along with antecedent Pleistocene topography (Lidz et al. 2006), is used to explain the modern distribution of reefs along the FKRT, which correlates with the presence and width of tidal passes. As documented early on by aerial photography, the most developed reefs are found in areas where tidal exchange is minimal (Marszalek et al. 1977). The spatial pattern in present-day coral coverage continues to reflect this, despite the degradation of coral populations over the past half-century (Burman et al. 2012).

There are many aspects of water quality that could contribute to the "inimical" status (with regards to reef growth) of waters flowing from Florida Bay and the West Florida Shelf. Water quality has been monitored on a quarterly basis throughout the Florida Keys (including the Dry Tortugas) since 1995, and has revealed geographical variation in many variables reflecting large-scale transport via circulation pathways and elucidating multiple nutrient sources (Boyer and Briceno 2010). A principal components analysis of the Boyer and Briceno (2010) data from 155 stations resulted in seven water-quality domains, with midchannel and offshore main Keys sites falling out together and in a different domain than the Dry Tortugas stations. While stations very close to the main Keys did show elevated levels of nutrients (Boyer and Briceno 2010), dissolved inorganic nutrients have not shown convincing onshore-offshore patterns beyond the landward portion of Hawk Channel (Szmant and Forrester 1996). Recent monitoring of the carbonate system variables has shown onshore-offshore and seasonal patterns in the main Keys (Manzello et al. 2012) and seasonal patterns in waters offshore of the Keys (Gledhill et al. 2008), but few data exist for the Dry Tortugas area. Two studies so far have attempted to link water quality and coral growth on the 
FKRT. Lirman and Fong (2007) found that coral community structure and linear extension rates did not correlate well with water quality. Cook et al. (2002) found no patterns in linear extension, but found a positive relationship between calcification rate and distance from the Channel \#5 tidal pass.

The lack of differentiation in calcification rates among the three main Keys sites indicates that the inimical waters hypothesis may need some refinement to be applicable to our results. In accord with the hypothesis, we expected to see faster calcification rates at Molasses Reef (protected from Florida Bay waters by the island of Key Largo) than at Sombrero Key (opposite the Seven Mile Bridge tidal pass that accounts for $50 \%$ of the volume transport through the Keys; Lee and Smith 2002). However, perhaps the shallow, nearshore waters not associated with the tidal passes (e.g., Hawk Channel itself) could also be considered "inimical" due to their large annual range in temperature (Hudson 1981b; Manzello et al. 2012). Records of a recent cold event, for example, illustrate this point. In January 2010, massive mortality of corals on nearshore patch reefs occurred along the length of the upper Keys (where there are few tidal passes) due to a cold front that cooled nearshore waters to below $16{ }^{\circ} \mathrm{C}$ for multiple days (Kemp et al. 2011; Lirman et al. 2011; Colella et al. 2012).

Light attenuation is another variable that warrants consideration in explaining the spatial variation in coral calcification that we observed. High levels of suspended particulate matter predicted low coral percent cover and carbonate production on reefs in the Coral Triangle (Edinger et al. 2000). Periodic increased turbidity due to wind mixing of fine, carbonate sediments is regularly observed in Hawk Channel, which turns a milky, nearly opaque aquamarine color when the surface winds are $>15-20$ knots (authors' personal observations). Since our calcification stations are $<6 \mathrm{~m}$ deep, light levels may be saturating during summer, but could be limited during windy periods and in winter when length of day is short and sun angles are low. The SEAKEYS program was intended to be our source of underwater light data, but the instruments were taken offline shortly after the inception of our calcification monitoring network due to lack of funding. Therefore, we are presently unable to make correlations between calcification rates and light extinction coefficients at our sites.

Bioerosion has also been linked to aspects of water quality. Most bioeroding organisms that infest, erode, and/ or dissolve reef structure and coral skeletons are filter feeders, and exchange with nearshore waters probably brings them a steady food supply (Hallock and Schlager 1986). Our corals at the Dry Tortugas site had the smallest proportion of their skeletons bored, followed by those at Fowey and then the other two sites. Highsmith (1980) found a strong correlation between global patterns in water-column productivity and the abundance of bioeroding infauna in museum specimens of coral skeletons from around the world, and field studies since then have shown similar patterns (Sammarco and Risk 1990; Harriott 1999; Chiappone and Sullivan 1997; Manzello et al. 2008).

The patterns in calcification and bioerosion revealed here are consistent with the water-column productivity hypothesis, but higher-frequency and more comprehensive (e.g., monitoring the carbonate system parameters) data will be required to determine what aspects of water quality could be responsible. Since we only measured net calcification (see Andersson and Mackenzie 2012), we cannot discern the relative contributions of gross calcification versus bioerosion rates in producing the patterns we observed. Also, much of the bioerosion that we quantified in our X-rays probably pre-dated the transplantation of the corals because most of the borings were below the alizarin stain line and the bioeroding community is very slow growing. However, linear extension showed similar patterns as calcification rate (greatest growth at Pulaski Shoal), indicating that gross calcification rates were at least partially responsible for the pattern observed.

Depending on species and location, patterns in calcification rate, linear extension, and skeletal density can correlate with one another positively, negatively, or not at all (Barnes and Crossland 1980; Carricart-Ganivet 2004), and all three vary throughout the year (Shinn 1966; Barnes and Crossland 1980). Because linear extension was significantly correlated with calcification rates measured in our study, one might question the need for measuring calcification rates. However, we found that the error within site was proportionally much larger than the variance among sites for linear extension compared to calcification rate, and the linear extension rate data were not normally distributed. In order to detect spatial or temporal differences, replication would have to be much higher using linear extension and density to calculate calcification rate than when measuring calcification rates directly. For example, the study by De'ath et al. (2009) examined 328 colonies to draw their conclusion that calcification rate has significantly declined over time on the Great Barrier Reef.

Whether or not a reef will accrete is controlled by the balance between rate of carbonate production by calcifiers and rate of carbonate breakdown by bioeroders (Hallock and Schlager 1986), but corals are not the only important calcifiers. While the net calcification rate of the CCA community was low compared to reef-building corals in this study (CCA $0.054 \mathrm{~g} \mathrm{~cm}^{-2} \mathrm{yr}^{-1}$ vs. $S$. siderea, $0.99 \mathrm{~g} \mathrm{~cm}^{-2} \mathrm{yr}^{-1}$ ), the percent cover by CCA is often much greater than that of live coral (Adey 1998). Given the CCA community's ubiquitous presence on the ocean floor (Steneck 1986), its important function as a positive 
settlement cue for coral larvae (Morse et al. 1988; Heyward and Negri 1999), its major role in the carbonate budget and in sediment production of most reefs (Adey and Macintyre 1973; Chisholm 2000), and its vulnerability to ocean acidification (Anthony et al. 2008; Kuffner et al. 2008; Albright et al. 2010), we recommend that systematic monitoring of CCA net accretion become an integral part of reef-monitoring programs. Presently, there are few data that we can directly compare to ours. CCA communities across our four FKRT sites had a mean carbonate accretion rate of $540 \mathrm{~g} \mathrm{~m}^{-2} \mathrm{yr}^{-1}$. A similar study using ceramic plates on the north side of Jamaica reported values of 128 and $159 \mathrm{~g} \mathrm{~m}^{-2} \mathrm{yr}^{-1}$ for two sites that were in habitats comparable to ours (Mallela 2007). Short-term incubation experiments on the GBR measuring calcification rates of four species of CCA reported rates as high as $3.3 \mathrm{~kg} \mathrm{~m}^{-2} \mathrm{yr}^{-1}$, but rates measured in this way would not include any loss from herbivory or other erosional factors (Chisholm 2000).

The patterns in net CCA accretion observed in our study indicate that CCA communities were responding to different variables than those controlling coral calcification. Nutrient availability and herbivory both positively affected CCA community accretion on Hawaiian reefs (Smith et al. 2001). The significantly higher CCA accretion documented at Sombrero Reef suggests a source of exogenous nutrients, since the number of parrotfish-bite marks was clearly greater at Fowey Rocks compared to the other three sites while CCA accretion was low. Direct flow from the largest tidal pass in the Florida Keys connecting Sombrero Reef with the West Florida Shelf is the most likely vector for the delivery of nutrient-enriched waters. The factors controlling CCA accretion at the four sites currently remain unknown, and quantification of the grazing community (e.g., parrotfish, territorial damselfish) will need to be integrated into future studies. Because CCA communities are so responsive to calcite saturation state (Kuffner et al. 2008), the carbonate system parameters need to be evaluated as well. This will require deployment of continuously monitoring instruments to be meaningful, though, since diurnal and seasonal variability in these parameters is quite large in nearshore waters (Yates and Halley 2006; Hofmann et al. 2011; Price et al. 2012).

Ocean acidification (OA) may impact reef accretion in the future but, at least for the FKRT, will probably not do so via direct, chronic impacts of OA on coral-calcification rates. Coral mortality (resulting from bleaching, cold-water stress, disease, etc.) will most likely continue to be the important driver of coral community structure (Burman et al. 2012) and, hence, community calcification rates on reefs (Kleypas et al. 2011). However, OA could be influential on reef trajectory by impacting early life-history phases that are essential to reef recovery, either by direct effects on coral recruits (Albright et al. 2008; Cohen et al. 2009) or indirectly, through OA impacts on the crustose coralline algal community (Kuffner et al. 2008; Albright et al. 2010; Albright and Langdon 2011). Regardless, a possible implication of differences in calcification rates among reef sites is that they will respond differently to future environmental changes. For example, reefs in the Dry Tortugas with higher calcification rates may take longer to show signs of chronic stress and could recover more quickly from major stress events (e.g., Lidz and Zawada 2013) than other reefs in the region. It is important that other coral species be investigated to see whether the spatial patterns in calcification are similar, especially those that are not as temperature tolerant as $S$. siderea.

This study was the first to systematically measure in situ calcification rates of whole coral colonies and the CCA community over multiple years in a reef-crest setting and provides a key baseline dataset to allow detection of change in the future. As fossil-fuel burning continues to alter the global carbon cycle by moving carbon from the Earth's crust to the atmosphere and the oceans (Mackenzie and Lerman 2006), there is further commitment to Earthsystem change (Meehl et al. 2005). Long-term, systematic measurement of calcification rates of reef-building organisms will allow us to document and quantify the potential impacts of chronic warming, altered water quality, and/or ocean acidification on the processes of calcification and reef construction.

Acknowledgments This study was principally funded by the US Geological Survey (USGS) Coastal and Marine Geology program with supplementary funds from the USGS Terrestrial, Freshwater, and Marine Ecosystems program and grants from the USGS Global Change Research fund and the Department of Interior Southeast Climate Science Center. Scholarly input from Brian Keller (FKNMS), who is greatly missed, was essential during the planning of the study. We thank the National Park Service crew of the M/V Ft. Jefferson (C. and J. Douglass, J. Spade) for their support in the Dry Tortugas. For field and laboratory help, we thank A. Brame, L. Goldberger, K. Ludwig, C. Reich, C. Reynolds, J. Sanford, and C. Williams. We thank C. Reich for preparing Fig. 1. The study was conducted under scientific permits FKNMS-2008-062A, FKNMS-2010-122, DRTO2009-SCI-0009, DRTO-2011-SCI-0004, BISC-2009-SCI-0019, BISC-2010-SCI-0035, and BISC-2011-SCI-0025. Any use of trade names herein was for descriptive purposes only and does not imply endorsement by the US Government.

Open Access This article is distributed under the terms of the Creative Commons Attribution License which permits any use, distribution, and reproduction in any medium, provided the original author(s) and the source are credited.

\section{References}

Adey WH (1998) Coral reefs: algal structured and mediated ecosystems in shallow, turbulent, alkaline waters. J Phycol 34:393-406 
Adey WH, Macintyre IG (1973) Crustose coralline algae: a reevaluation in the geological sciences. Geol Soc Am Bull 84:883-904

Albright R, Langdon C (2011) Ocean acidification impacts multiple early life history processes of the Caribbean coral Porites astreoides. Global Change Biol 17:2478-2487

Albright R, Mason B, Langdon C (2008) Effect of aragonite saturation state on settlement and post-settlement growth of Porites astreoides larvae. Coral Reefs 27:485-490

Albright R, Mason B, Miller M, Langdon C (2010) Ocean acidification compromises recruitment success of the threatened Caribbean coral Acropora palmata. Proc Natl Acad Sci USA 107:20400-20404

Andersson AJ, Mackenzie FT (2012) Revisiting four scientific debates in ocean acidification research. Biogeosciences 9:893-905

Anthony KRN, Kline DI, Diaz-Pulido G, Dove S, Hoegh-Guldberg O (2008) Ocean acidification causes bleaching and productivity loss in coral reef builders. Proc Natl Acad Sci USA 105:17442-17446

Aronson RB, Bruno JF, Precht WF, Glynn PW, Harvell CD, Kaufman L, Rogers CS, Shinn EA (2003) Causes of coral reef degradation. Science 302:1502-1504

Barnes DJ, Crossland CJ (1980) Diurnal and seasonal variations in the growth of a staghorn coral measured by time-lapse photography. Limnol Oceanogr 25:1113-1117

Bates NR (2007) Interannual variability of the oceanic $\mathrm{CO}_{2}$ sink in the subtropical gyre of the North Atlantic Ocean over the last 2 decades. J Geophys Res 112:1-26

Boyer JN, Briceno HO (2010) 2010 annual report of the Water Quality Monitoring Project for the Florida Keys National Marine Sanctuary. Southeast Environmental Research Center, Florida International University, Miami, p 82

Burman SG, Aronson RB, van Woesik R (2012) Biotic homogenization of coral assemblages along the Florida reef tract. Mar Ecol Prog Ser 467:89-96

Carricart-Ganivet JP (2004) Sea surface temperature and the growth of the West Atlantic reef-building coral Montastraea annularis. J Exp Mar Biol Ecol 302:249-260

Carricart-Ganivet JP (2011) Coral skeletal extension rate: An environmental signal or a subject to inaccuracies? J Exp Mar Biol Ecol 405:73-79

Castillo KD, Ries JB, Weiss JM (2011) Declining coral skeletal extension for forereef colonies of Siderastrea siderea on the Mesoamerican Barrier Reef System, southern Belize. PLOS ONE 6:1-12

Chiappone M, Sullivan KM (1997) Rapid assessment of reefs in the Florida Keys: results from a synoptic survey. Proc 8th Int Coral Reef Symp 2:1509-1514

Chisholm JRM (2000) Calcification by crustose coralline algae on the northern Great Barrier Reef, Australia. Limnol Oceanogr 45:1476-1484

Chollett I, Muller-Karger FE, Heron SF, Skirving W, Mumby PJ (2012) Seasonal and spatial heterogeneity of recent sea surface temperature trends in the Caribbean Sea and southeast Gulf of Mexico. Mar Pollut Bull 64:956-965

Cohen AL, McCorkle DC, de Putron S, Gaetani GA, Rose KA (2009) Morphological and compositional changes in the skeletons of new coral recruits reared in acidified seawater: Insights into the biomineralization response to ocean acidification. Geochem Geophys Geosyst 10:1-12

Colella MA, Ruzicka RR, Kidney JA, Morrison JM, Brinkhuis VB (2012) Cold-water event of January 2010 results in catastrophic benthic mortality on patch reefs in the Florida Keys. Coral Reefs 31:621-632
Coles SL, Jokiel PL (1978) Synergistic effects of temperature, salinity and light on the hermatypic coral Montipora verrucosa. Mar Biol 49:187-195

Cook CB, Mueller EM, Ferrier MD, Annis E (2002) The influence of nearshore waters on corals of the Florida reef tract. In: Porter JW, Porter KG (eds) The Everglades, Florida Bay, and coral reefs of the Florida Keys: an ecosystem sourcebook. CRC Press, Boca Raton, pp 771-788

Cooper TF, De'ath G, Fabricius KE, Lough JM (2008) Declining coral calcification in massive Porites in two nearshore regions of the northern Great Barrier Reef. Global Change Biol 14:529-538

Cooper TF, O'Leary RA, Lough JM (2012) Growth of Western Australian corals in the Anthropocene. Science 335:593-596

De'ath G, Lough JM, Fabricius KE (2009) Declining coral calcification on the Great Barrier Reef. Science 323:116-119

DeLong KL, Flannery JA, Maupin CR, Poore RZ, Quinn TM (2011) A coral $\mathrm{Sr} / \mathrm{Ca}$ calibration and replication study of two massive corals from the Gulf of Mexico. Palaeogeogr Palaeoclimatol Palaeoecol 307:117-128

Dennison WC, Barnes DJ (1988) Effect of water motion on coral photosynthesis and calcification. J Exp Mar Biol Ecol 115:67-77

Dodge RE, Brass GW (1984) Skeletal extension, density and calcification of the reef coral, Montastrea annularis: St. Croix, U.S. Virgin Islands. Bull Mar Sci 34:288-307

Edinger EN, Limmon GV, Jompa J, Widjatmoko W, Heikoop JM, Risk MJ (2000) Normal coral growth rates on dying reefs: Are coral growth rates good indicators of reef health? Mar Pollut Bull 40:404-425

Fabricius KE (2005) Effects of terrestrial runoff on the ecology of corals and coral reefs: review and synthesis. Mar Pollut Bull 50:125-146

Falkowski PG, Jokiel PL, Kinzie RA (1990) Irradiance and corals. In: Dubinsky Z (ed) Ecosystems of the world: Coral reefs. Elsevier Science Publishers, Amsterdam, pp 89-107

Frieler K, Meinshausen M, Golly A, Mengel M, Lebeck K, Donner SD, Hoegh-Guldberg $\mathrm{O}$ (2013) Limiting global warming to $2{ }^{\circ} \mathrm{C}$ is unlikely to save most coral reefs. Nature Clim Change 3:165-170

Gattuso JP, Frankignoulle M, Bourge I, Romaine S, Buddemeier RW (1998) Effect of calcium carbonate saturation of seawater on coral calcification. Global Planet Change 18:37-46

Gibson PJ, Boyer JN, Smith NP (2008) Nutrient mass flux between Florida Bay and the Florida Keys National Marine Sanctuary. Estuaries and Coasts 31:21-32

Ginsburg RN, Shinn EA (1994) Preferential distribution of reefs in the Florida reef tract: the past is the key to the present. In: Ginsburg RN (ed) Proceedings of the colloquium on global aspects of coral reefs: Health, hazards and history. University of Miami, Miami, pp 21-26

Gledhill DK, Wanninkhof R, Millero FJ, Eakin M (2008) Ocean acidification of the Greater Caribbean Region 1996-2006. J Geophys Res 113:1-11

Hallock P, Schlager W (1986) Nutrient excess and the demise of coral reefs and carbonate platforms. Palaios 1:389-398

Harriott VJ (1999) Coral growth in subtropical eastern Australia. Coral Reefs 18:281-291

Helmle KP, Dodge RE, Swart PK, Gledhill DK, Eakin CM (2011) Growth rates of Florida corals from 1937 to 1996 and their response to climate change. Nat Communications 2:215

Heyward AJ, Negri AP (1999) Natural inducers for coral larval metamorphosis. Coral Reefs 18:273-279

Highsmith RC (1980) Geographic patterns of coral bioerosion: a productivity hypothesis. J Exp Mar Biol Ecol 46:177-196

Hofmann GE, Smith JE, Johnson KS, Send U, Levin LA, Micheli F, Paytan A, Price NN, Peterson B, Takeshita Y, Matson PG, Derse Crook E, Kroeker KJ, Cristina Gambi M, Rivest EB, Frieder CA, 
Yu PC, Martz TR (2011) High-frequency dynamics of ocean pH: A multi-ecosystem comparison. PLOS ONE 6:e28983

Hudson JH (1981a) Growth rates in Montastrea annularis: a record of environmental change in Key Largo Coral Reef Marine Sanctuary, Florida. Bull Mar Sci 31:444-459

Hudson JH (1981b) Response of Montastrea annularis to environmental change in the Florida Keys. Proc 4th Int Coral Reef Symp 2:233-240

Hudson JH (1983) Growth history of Montastrea annularis at Looe Key National Marine Sanctuary, Florida. In: Bohnsack JA (ed) Resource survey of Looe Key National Marine Sanctuary. NOAA Technical Memorandum NMFS-SEFSC-478, pp 91-111

Hughes TP, Graham NAJ, Jackson JBC, Mumby PJ, Steneck RS (2010) Rising to the challenge of sustaining coral reef resilience. Trends Ecol Evol 25:633-642

Jackson BC, Kirby MX, Berger WH, Bjorndal KA, Botsford LW, Bourque BJ, Bradbury RH, Cooke R, Erlandson J, Estes JA, Hughes TP, Kidwell S, Lange CB, Lenihan HS, Pandolfi JM, Peterson CH, Steneck RS, Tegner MJ, Warner RR (2001) Historical overfishing and the recent collapse of coastal ecosystems. Science 293:629-638

Jokiel PL (1978) Effects of water motion on reef corals. J Exp Mar Biol Ecol 35:87-97

Jokiel PL, Coles SL (1977) Effects of temperature on the mortality and growth of Hawaiian reef corals. Mar Biol 43:201-208

Jokiel PL, Coles SL (1990) Response of Hawaiian and other IndoPacific reef corals to elevated temperature. Coral Reefs 8:155-162

Jokiel PL, Maragos JE, Franzisket L (1978) Coral growth: buoyant weight technique. In: Stoddart DR, Johannes RE (eds) Coral reefs: research methods. UNESCO, Paris, pp 529-541

Jokiel PL, Rodgers KS, Kuffner IB, Andersson AJ, Cox EF, Mackenzie FT (2008) Ocean acidification and calcifying reef organisms: a mesocosm investigation. Coral Reefs 27:473-483

Keller BD, Causey BD (2005) Linkages between the Florida Keys National Marine Sanctuary and the South Florida Ecosystem Restoration Initiative. Ocean Coast Manage 48:869-900

Kemp DW, Oakley CA, Thornhill DJ, Newcomb LA, Schmidt GW, Fitt WK (2011) Catastrophic mortality on inshore coral reefs of the Florida Keys due to severe low-temperature stress. Global Change Biol 17:3468-3477

Kleypas JA, Anthony KRN, Gattuso JP (2011) Coral reefs modify their seawater carbon chemistry - case study from a barrier reef (Moorea, French Polynesia). Global Change Biol 17:3667-3678

Knutson DW, Buddemeier RW, Smith SV (1972) Coral chronometers: seasonal growth bands in reef corals. Science 177:270-272

Kuffner IB, Andersson AJ, Jokiel PL, Rodgers KS, Mackenzie FT (2008) Decreased abundance of crustose coralline algae due to ocean acidification. Nature Geosci 1:114-117

Lee TN, Smith N (2002) Volume transport variability through the Florida Keys tidal channels. Cont Shelf Res 22:1361-1377

Lidz BH, Shinn EA (1991) Paleoshorelines, reefs, and a rising sea: South Florida, U.S.A. J Coast Res 7:203-229

Lidz BH, Zawada DG (2013) Possible return of Acropora cervicornis at Pulaski Shoal, Dry Tortugas National Park, Florida. J Coast Res 29:256-271

Lidz BH, Reich CD, Peterson RL, Shinn EA (2006) New maps, new information: coral reefs of the Florida Keys. J Coast Res 22:260-282

Lirman D, Fong P (2007) Is proximity to land-based sources of coral stressors an appropriate measure of risk to coral reefs? An example from the Florida Reef Tract. Mar Pollut Bull 54:779-791

Lirman D, Schopmeyer S, Manzello D, Gramer LJ, Precht WF, Banks $\mathrm{K}$, Barnes B, Bartels E, Bourque A, Byrne J, Donahue S, Duquesnel J, Fisher L, Gilliam D, Hendee J, Johnson M,
Maxwell K, McDevitt E, Monty J, Rueda D, Ruzicka R, Thanner S (2011) Severe 2010 cold-water event caused unprecedented mortality to corals of the Florida reef tract and reversed previous survivorship patterns. PLOS ONE 6:e23047

Mackenzie FT, Lerman A (2006) Carbon in the geobiosphere Earth's outer shell. Springer, Dordrecht, p 402

Mallela J (2007) Coral reef encruster communities and carbonate production in cryptic and exposed coral reef habitats along a gradient of terrestrial disturbance. Coral Reefs 26:775-785

Manzello DP, Kleypas JA, Budd DA, Eakin CM, Glynn PW, Langdon C (2008) Poorly cemented coral reefs of the eastern tropical Pacific: Possible insights into reef development in a high- $\mathrm{CO}_{2}$ world. Proc Natl Acad Sci USA 105:10450-10455

Manzello DP, Enochs IC, Melo N, Gledhill DK, Johns EM (2012) Ocean acidification refugia of the Florida Reef Tract. PLoS ONE 7:e41715

Marszalek DS, Babashoff G Jr, Noel MR, Worley DR (1977) Reef distribution in South Florida. Proc 3rd Int Coral Reef Symp 2:223-229

Marubini F, Atkinson MJ (1999) Effects of lowered pH and elevated nitrate on coral calcification. Mar Ecol Prog Ser 188:117-121

Marubini F, Davies PS (1996) Nitrate increases zooxanthellae population density and reduces skeletogenesis in corals. Mar Biol 127:319-328

Marubini F, Ferrier-Pages C, Cuif JP (2003) Suppression of skeletal growth in scleractinian corals by decreasing ambient carbonateion concentration: a cross-family comparison. Proc R Soc Lond B Biol Sci 270:179-184

Meehl GA, Washington WM, Collins WD, Arblaster JM, Hu A, Buju LE, Strand WG, Teng H (2005) How much more global warming and sea level rise? Science 307:1769-1772

Morse DE, Hooker N, Morse ANC, Jensen RA (1988) Control of larval metamorphosis and recruitment in sympatric agariciid corals. J Exp Mar Biol Ecol 116:193-217

Ohde S, Van Woesik R (1999) Carbon dioxide flux and metabolic processes of a coral reef, Okinawa. Bull Mar Sci 65:559-576

Palandro DA, Andrefouet S, Hu C, Hallock P, Muller-Karger FE, Dustan P, Callahan MK, Kranenburg C, Beaver CR (2008) Quantification of two decades of shallow-water coral reef habitat decline in the Florida Keys National Marine Sanctuary using Landsat data (1984-2002). Remote Sens Environ 112:3388-3399

Pandolfi JM, Bradbury RH, Sala E, Hughes TP, Bjorndal KA, Cooke RG, McArdle D, McClenachan L, Newman MJH, Peredes G, Warner RR, Jackson JBC (2003) Global trajectories of the longterm decline of coral reef ecosystems. Science 301:955-958

Pandolfi JM, Jackson JBC, Baron N, Bradbury RH, Guzman HM, Hughes TP, Kappel CV, Micheli F, Ogden JC, Possingham HP, Sala E (2005) Are U.S. coral reefs on the slippery slope to slime? Science 307:1725-1726

Price NN, Martz TR, Brainard RE, Smith JE (2012) Diel variability in seawater $\mathrm{pH}$ relates to calcification and benthic community structure on coral reefs. PLOS ONE 7:e43843

Reynaud S, Leclercq N, Romaine-Lioud S, Ferrier-Pages C, Jaubert J, Gattuso JP (2003) Interacting effects of $\mathrm{CO}_{2}$ partial pressure and temperature on photosynthesis and calcification in a scleractinian coral. Global Change Biol 9:1660-1668

Risk MJ (1999) Paradise lost: how marine science failed the world's coral reefs. Mar Freshw Res 50:831-837

Roberts HH, Rouse JRLJ, Walker ND, Hudson JH (1982) Cold-water stress in Florida Bay and northern Bahamas: a product of winter cold-air outbreaks. J Sediment Petrol 52:0145-0155

Sammarco PW, Risk MJ (1990) Large-scale patterns in internal bioerosion of Porites: cross continental shelf trends on the Great Barrier Reef. Mar Ecol Prog Ser 59:145-156

Shinn EA (1966) Coral growth-rate, an environmental indicator. J Paleontol 40:233-240 
Shinn EA (1980) Geologic history of Grecian Rocks, Key Largo Coral Reef Marine Sanctuary. Bull Mar Sci 30:646-656

Shinn EA, Hudson JH, Halley RB, Lidz B (1977) Topographic control and accumulation rate of some Holocene coral reefs: South Florida and Dry Tortugas. Proc 3rd Int Coral Reef Symp 2:1-7

Smith JE, Smith CM, Hunter CL (2001) An experimental analysis of the effects of herbivory and nutrient enrichment on benthic community dynamics on a Hawaiian reef. Coral Reefs 19:332-342

Steneck RS (1986) The ecology of coralline algal crusts: convergent patterns and adaptive strategies. Annu Rev Ecol Syst 17:273-303

Szmant AM, Forrester A (1996) Water column and sediment nitrogen and phosphorus distribution patterns in the Florida Keys, USA. Coral Reefs 15:21-41

Tanzil JTI, Brown BE, Tudhope AW, Dunne RP (2009) Decline in skeletal growth of the coral Porites lutea from the Andaman Sea, South Thailand between 1984 and 2005. Coral Reefs 28:519-528
Vasquez-Bedoya LF, Cohen AL, Oppo DW, Blanchon P (2012) Corals record persistent multidecadal SST variability in the Atlantic Warm Pool since 1775 AD. Paleoceanography 27:pa3231

Veron JEN, Hoegh-Guldberg O, Lenton TM, Lough JM, Obura DO, Pearce-Kelly P, Sheppard CRC, Spalding M, Stafford-Smith MG, Rogers AD (2009) The coral reef crisis: The critical importance of $<350 \mathrm{ppm} \mathrm{CO}_{2}$. Mar Pollut Bull 58:1428-1436

Voss GL (1973) Sickness and death in Florida's coral reefs. Nat Hist 72:41-47

Winter A, Appeldoorn RS, Bruckner A, Williams EH, Goenaga C (1998) Sea surface temperatures and coral reef bleaching off La Parguera, Puerto Rico (northeastern Caribbean Sea). Coral Reefs 17:377-382

Yates KK, Halley RB (2006) Diurnal variation in rates of calcification and carbonate sediment dissolution in Florida Bay. Estuaries and Coasts 29:24-39 